JOTE Volume 2 Nomor 1 Tahun 2020 Halaman 9 - 17 JOURNAL ON TEACHER EDUCATION

Research \& Learning in Faculty of Education

\title{
Peningkatan Komitmen Tugas Terhadap Kompetensi Pedagogik Guru Melalui Peran Kepala Sekolah di SMA Negeri 1 Bola
}

\author{
Florius Lepe \\ SMA Negeri 1 Bola, Sikka, NTT \\ Email: floriuslepe@gmail.com
}

\begin{abstract}
Abstrak
Penelitian Tindakan Sekolah ini mempunyai tujuan untuk meningkatkan kompetensi pedagogik guru melalui peran kepala sekolah di SMA Negeri 1 Bola. Penelitian Tindakan Sekolah ini terdiri dari 2 siklus, dan tiap siklus terdiri dari 4 tahapan yaitu perencanaan, pelaksanaan, observasi dan refleksi. Adapun indikator keberhasilan adalah penelitian ini dikatakan berhasil jika terjadi peningkatan hasil skor rata- rata komitmen tugas minimal $80 \%$ dengan kategori tinggi dan kompetensi pedagogik minimal 65\% guru rata-rata mencapai kriteria amat baik. Hasil penelitian menunjukkan bahwa: 1) terjadi komitmen tugas dengan nilai rata-rata $74,41 \%$ termasuk pada kategori sedang pada siklus pertama dan pada siklus kedua mencapai nilai rata-rata $81,93 \%$ termasuk pada kategori tinggi. 2) ativitas pegagogik pada siklus pertama rata-rata $65,4 \%$ dan siklus kedua $73,2 \%$. Terjadi peningkatan komitmen tugas dengan nilai rata-rata $74,41 \%$ termasuk pada kategori sedang pada siklus pertama dan pada siklus kedua mencapai nilai rata-rata $81,93 \%$ termasuk pada kategori tinggi. Kompetensi pedagogik guru dengan nilai rata-rata $65,4 \%$ pada siklus pertama dan rata-rata $73,2 \%$ dengan ini bahwa penelitian dikatakan berhasil.
\end{abstract}

Kata Kunci: Komitmen Tugas, Kompetensi Pedagogik

Abstract

This school action research aims to improve teacher pedagogical competence through the role of the principal in SMA Negeri 1 Bola. This School Action Research consists of 2 cycles, and each cycle consists of 4 stages, namely planning, implementing, observing and reflecting. The indicator of success is this research is said to be successful if there is an increase in the average score of assignment commitment of at least $80 \%$ with a high category and a pedagogic competence of at least $65 \%$ of teachers on average achieve very good criteria. The results showed that: 1 ) there was a duty commitment with an average value of $74.41 \%$ including in the medium category in the first cycle and in the second cycle reaching an average value of $81.93 \%$ including in the high category. 2) the average pegagogic activity in the first cycle is $65.4 \%$ and the second cycle is $73.2 \%$. There was an increase in task commitment with an average value of $74.41 \%$ including in the medium category in the first cycle and in the second cycle reaching an average value of $81.93 \%$ including in the high category. Teacher pedagogic competence with an average score of $65.4 \%$ in the first cycle and an average of $73.2 \%$, with this that the research is said to be successful.

Keywords: Task Commitment, Pedagogic Competence 


\section{PENDAHULUAN}

Guru memiliki peran yang sangat penting dalam pendidikan formal dalam rangka meningkatkan kualitas peserta didik. Oleh karena itu diperlukan guru profesional untuk mendukung peningkatan kualitas pembelajaran di sekolah. Guru sebagai tenaga profesional diharuskan memiliki kompetensi profesional, di samping kompetensi pedagogik, kompetensi kepribadian, dan kompetensi sosial. Tanpa bermaksud mengabaikan salah satu kompetensi yang ada, dalam penelitian ini hanya akan dibahas tentang kompetensi pedagogik guru. Menurut Marselus R. Payong (2011: 28-29) pedagogik berarti membimbing/mengatur anak. Tugas membimbing ini melekat dalam tugas seorang pendidik, maka guru tidak hanya sebagai pengajar yang mentransfer ilmu pengetahuan dan keterampilan kepada siswa, tetapi juga merupakan pendidik dan pembimbing yang membantu siswa untuk mengembangkan segala potensinya baik itu potensi akademik maupun non akademik. Dalam kegiatan pembelajaran, kompetensi yang dominan harus dimiliki guru adalah kompetensi pedagogik. Kompetensi ini merupakan rambu-rambu yang harus dijadikan pedoman guru dalam proses pembelajaran.

Menurut Arikunto (2004: 23), kegiatan pokok kepala sekolah adalah melakukan pembinaan kepada personil sekolah pada umumnya dan khususnya guru, agar kualitas pembelajarannya meningkat atau sering disebut dengan supervisi. Supervisi diartikan sebagai kegiatan yang dilakukan oleh kepala sekolah atau pejabat yang berkedudukan di atas atau lebih tinggi dari guru untuk melihat atau mengawasi petugasan guru. Supervisi bertugas melihat dengan jelas masalah- masalah yang muncul dalam mempengaruhi situasi belajar dan menstimulir guru ke arah usaha perbaikan.

Konskuensi logis bahwa seorang guru harus siap disupervisi setiap saat, karena adanya kepala sekolah akan mampu meningkatkan kompetensi pedagogik guru. Mengingat di SMA Negeri 1 Bola belum sepenuhnya supervisi dilaksanakan secara terjadwal dan periodik, sehingga hasil yang dicapai dari kegiatan ini belum tepat sasaran. Guru membutuhkan kepala sekolah yang bersifat kunjungan kelas, sehingga guru bisa mendapatkan masukan mengenai cara mengajarnya apakah sudah baik atau masih ada beberapa hal yang perlu ditingkatkan. Selain itu, supervisi tersebut dilakukan untuk mengetahui kesesuaian pembelajaran dengan kurikulum yang sedang diterapkan saat ini. Salah satu bentuk langkah perbaikan pembelajaran adalah danya peran kepala sekolah dengan melakukan supervisi akademik.

Peran kepala sekolah adalah membantu guru memahami isu-isu dan membuat keputusan yang bijak yang dapat mempengaruhi pendidikan peserta didik secara positif. Dalam hal ini kepala sekolah berperan sebagai mitra, innovator dan pelopor, konsultan, dan motivator. Salah satu peran kepala sekolah diantaranya sebagai motivator. Kepala sekolah harus memiliki strategi yang tepat untuk memberikan motivasi kepada tenaga kependidikan dalam melaksanakan tugas dan fungsinya. Hal tersebut dikarenakan motivasi merupakan faktor yang dominan dan dapat menggerakkan faktor-faktor lain ke arah efektifitas tugas. Pentingnya peran kepala sekolah dilakukan agar kepala sekolah dapat lebih memahami tugas dan kewajibannya secara mendalam. Hal ini sejalan dengan penelitian Fred C. Lunenburg (2013) menemukan bahwa 
sekolah yang efektif memiliki kepala sekolah yang menunjukkan kepemimpinan kurikulum instruksional yang kuat serta keterampilan manajemen esensial.

Selain peran kepala sekolah, komitmen tugas guru juga merupakan salah satu faktor yang dapat mempengaruhi kompetensi pedagogik guru disekolah menengah. Komitmen guru merupakan salah satu bentuk pelaksanaan tanggung jawabnya sebagai seorang guru. Komitmen guru merupakan penafsiran internal seorang guru tentang bagaimana mereka menyerap dan memaknai pengalaman tugas mereka (Solomon, 2007:14). Komitmen guru dalam menjalankan tugas berperan penting dalam peningkatan kompetensi pedagogik. Komitmen ini meliputi, aspek komitmen pada lembaga, pada petugasan, pada kedudukan, komitmen pada kelompok tugas. Guru yang memiliki komitmen kuatkan betugas ekstra, dengan menggunakan kompetensi, waktu, tenaga, pikiran dan pengorbanan melebihi dari standar normal aturan main dalam sekolah. Guru mendapatkan penghargaan karena prestasi bagus dan hukuman bagi yang melanggar aturan main tentu menjadi notivasi tersendiri untuk menghasilkan kinerja yang baik bagi guru.

Kompetensi pedagogik adalah kemampuan mengelola pembelajaran peserta didik yang meliputi pemahaman terhadap peserta didik, perancangan dan pelaksanaan pembelajaran, evaluasi hasil belajar dan pengembangan peserta didik untuk mengaktualisasikan berbagai potensi yang dimilikinya. Oleh karena itu, guru di SMA Negeri 1 Bola perlu meningkatkan kualifikasi akademiknya dan dituntut untuk komitmen terhadap profesionalisme dalam mengemban tugasnya.

Seorang guru dikatakan memiliki komitmen tugas guru bila mana pada dirinya melekat sikap dedikasi yang tinggi terhadap tugasnya, sikap komitmen terhadap mutu proses dan hasil tugas, serta sikap yang selalu berusaha memperbaiki dan memperbaharui model-model atau cara tugasnya sesuai dengan tuntutan zaman, yang dilandasi oleh kesadaran yang tinggi bahwa tugas mendidik adalah tugas menyiapkan generasi penerus yang akan hidup pada zamannya dimasa depan.

Dari uraian di atas, maka tujuan dalam penelitian ini adalah menkaji peningkatan komitmen tugas terhadap kompetensi pedagogik guru di SMA Negeri 1 Bola melalui peran Kepala Sekolah. Dengan kajian tersebut, maka diharapkan diperoleh informasi untuk memperluas pemahaman Guru Sekolah Menengah tentang peran, peran kepala sekolah, dan komitmen tugas guru, juga dapat digunakan sebagai dasar pelaksanaan penelitian-penelitian selanjutnya, untuk mendapatkan hasil yang lebih sempurna dan untuk menambah keilmuan pendidikan.

\section{METODE}

Penelitian tindakan Sekolah ini dilaksanakan di SMA Negeri 1 Bola dari bulan Agustus sampai dengan Oktober 2018. Dalam penelitian ini yang menjadi subyek penelitian adalah guru di SMA Negeri 1 Bola dengan jumlah 23 orang. Objek dalam penelitian ini adalah komitmen tugas terhadap kompetensi pedagogik guru SMA Negeri 1 Bola. 


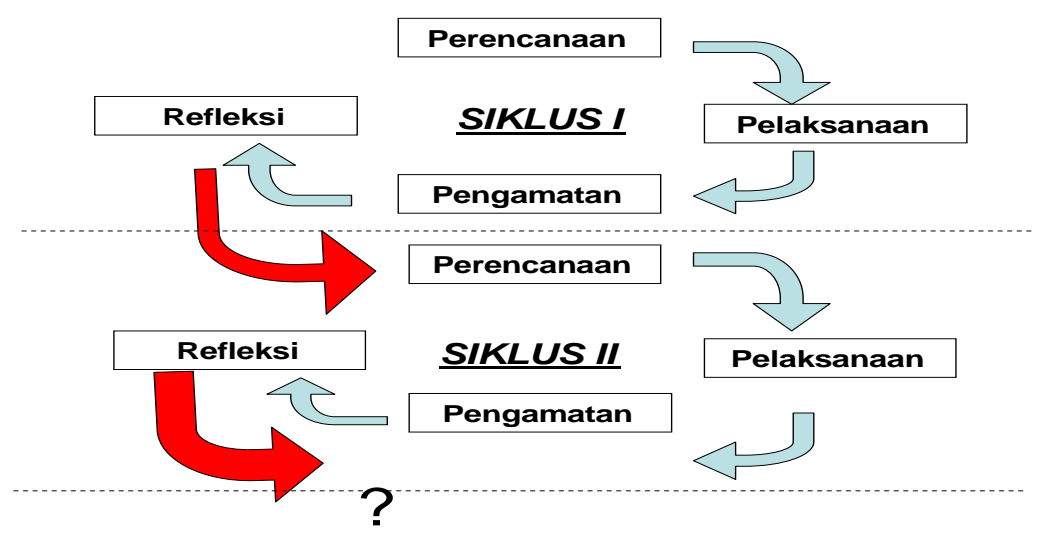

Gambar 1. Diagram Langkah-langkah PTS (Direktorat Tendik, 2008)

\section{Siklus Pertama}

Perencanaan yang dilakukan adalah:1) Sosialisasi PTS. 2) Dalam mengidentifikasi dan merumuskan masalah, peneliti berkolaborasi dengan wakasek Kurikulum. 3) Membuat rencana supervisi kelas. 4) Menyusun jadwal supervisi. 5) Meyusun instrumen penelitian diantaranya angket komitmen tugas dan lembar pengamatan kompetensi pedagogik guru. 6) Mempersiapkan daftar hadir. Pelaksanaan siklus pertama diantaranya: Menjelaskan kegiatan PTS untuk meningkatkan komitmen tugas terhadap kompetensi pedagogik dengan adanya kegiatan supervisi yang akan dilakukan oleh, kepala sekolah dibantu oleh wakasek kurikulum. 2). Mengadakan pembimbingan proses pembelajaran. 3). Berdiskusi antara peneliti dan guru. 4). Guru mengisi angket komitmen tugas 5). Menarik kesimpulan,

Observasi yang diperoleh peneliti dengan kolaborator berdasarkan angket komitmen tugas serta hasil observasi kompetensi pedagogik guru dianalisis agar diperoleh hasil yang objektif. Hasil diskusi digunakan untuk perencanaan, melaksanakan dan merefleksi pada siklus kedua.

Refleksi Setelah pelaksanaan supervisi kelas, peneliti dan observer berdiskusi dan menganalisa apa yang telah dilaksanakan. Dari hasil pengamatan serta pengisian angket kemudian diperoleh kekurangan dan kelebihan sebagai berikut: 1) guru yang kurang memahami proses pembelajaran. 2) Guru yang kurang memahami komitmen tugas. 3). Guru perlu melaksanakan proses pembelajaran yang benar. 4) Guru perlu memiliki komitmen tugas yang baik agar kompetensi pedagogiknya meningkat. Yang selanjutnya dipergunakan sebagai dasar untuk menyusun langkah pada siklus II.

\section{Siklus Kedua}

Perencanaan pada siklus kedua adalah: 1) Dalam mengidentifikasi dan merumuskan masalah, peneliti berkolaborasi dengan wakasek Kurikulum 2) Membuat rencana supervisi kelas untuk siklus kedua 3) Menyiapkan lembar observasi dan angket 4) Menganalisa hasil supervisi pada siklus kedua dengan bantuan observer.

Pelaksanaan siklus kedua berdasarkan hasil refleksi siklus pertama diantaranya: 1) Menginformasikan hasil supervisi pada siklus pertama. 2) berdiskusi antara peneliti, observer dan guru. 3) Guru mengisi angket komitmen tugas. 4) Menarik kesimpulan. Hasil yang dicapai oleh peneliti saat pengamatan 
proses pembelajaran dan angket. Kemudian dianalisis oleh peneliti dan berkolaborasi dengan cara berdiskusi agar diperoleh hasil yang objektif. Proses pembelajaran dikelas sudah benar sesuai dengan standar. Dengan demikian terjadi peningkatan komitmen tugas terhadap kompetensi pedagogic.

Observasi Selama pelaksanaan siklus kedua berlangsung, peneliti dan observer mengamati proses pembelajaran guru. Dari data observasi dan angket dianalisis oleh peneliti dan kolaborasi dengan cara berdiskusi dan berkoordinasi. Hasil diskusi digunakan untuk merefleksi pada siklus kedua.

Refleksi pada akhir siklus II ini diadakan refleksi berdasarkan data/hasil observasi serta angket oleh peneliti dan kolaborator yang dilakukan dalam penelitian ini. Apabila terjadi peningkatan komitmen tugas terhadap kompetensi pedagogik guru, maka penelitian dapat dihentikan sampai pada siklus II, namun bila penelitian belum mencapai indikator keberhasilan yang telah ditetapkan maka penelitian dilanjutkan pada siklus berikutnya.

Instrumen yang digunakan untuk memperoleh data yang diperlukan dalam penelitian ini terdiri atas observasi, angket dan dokumentasi. Kriteria keberhasilan ditekankan pada peningkatan komitmen tugas terhadap kompetensi pedagogik guru.

\section{HASIL DAN PEMBAHASAN}

\section{Siklus Pertama \\ Perencanaan}

Sosialisasi PTS, peneliti atau kepala sekolah berkolaborasi dengan wakasek Kurikulum, membuat rencana supervisi kelas, menyusun jadwal supervisi bersama kepala sekolah, meyusun instrumen penelitian diantaranya angket komitmen tugas dan lembar pengamatan kompetensi pedagogik guru, mempersiapkan daftar hadir.

\section{Pelaksanaan}

Siklus I dilakukan dari tanggal 1-15 September 2018 pukul 08.00 sampai dengan pukul 12.00 diadakan sosialisasi kegiatan PTS untuk meningkatkan komitmen tugas terhadap kompetensi pedagogik dengan adanya kegiatan supervisi yang akan dilakukan oleh, kepala sekolah dibantu oleh wakasek kurikulum sebagai kolaborator. Kepala sekolah mengadakan pengarahan tentang langkah-langkah proses pembelajaran yang benar serta fokus pada komitmen tugas sebagai guru guna meningkatkan kompetensi pedagogik. Peneliti mengadakan diskusi dan tanya jawab bersama guru. Kemudian guru mengisi angket komitmen tugas yang dibagikan oleh kepala sekolah secara jujur. Dari tanggal 3-14 September 2018 diadakan supervisi kelas sesuai dengan jadwal mengajar oleh peneliti, kepala sekolah dan wakasek kurikulum. Dan pada tanggal 15 September 2018 diadakan pertemuan untuk menarik kesimpulan dari hasil yang dicapai oleh peneliti saat pengamatan proses pembelajaran dan angket.

\section{Hasil observasi}

Pada observasi diperoleh hasil Penilaian melalui kompetensi pedagogik guru SMA Negeri 1 Bola pada siklus pertama 5 orang atau $22 \%$ guru dengan kriteria amat baik, 15 orang atau $64 \%$ dengan kategori baik dan 3 orang 
atau $14 \%$ dengan kategori cukup. Hasil angket komitmen tugas pada siklus pertama diantaranya bahwa kategori sangat tinggi hanya 1 orang, kategori tinggi 6 orang, kategori sedang 11 orang dan kategori rendah ada 5 orang dengan rata-rata nilai 74,41 termasuk pada kategori sedang.

\section{Refleksi}

Pada saat refleksi masih ada beberapa hal yang perlu diperbaiki, yaitu :1) Kompetensi pedagogik guru yang hanya mencapai nilai rata-rata $65,4 \%$ dengan rincian sebagai berikut: 5 orang atau $22 \%$ guru dengan kriteria amat baik, 15 orang atau $64 \%$ dengan kategori baik dan 3 orang atau $14 \%$ dengan kategori cukup. Minimal pada siklus berikutnya rata-rata nilai kompetensi pedagogik mencapai kategori baik dan memenuhi kriteria indikator keberhasilan yaitu minimal $65 \%$ guru rata-rata mencapai kriteria amat baik. 2) Dari hasil angket komitmen tugas yang diberikan kepada guru, menyatakan bahwa kategori sangat tinggi hanya 1 orang, kategori tinggi 6 orang, kategori sedang 11 orang dan kategori rendah ada 5 orang dengan rata-rata nilai 74,41 termasuk pada kategori sedang.

\section{Siklus Kedua}

Perencanaan

Antaranya :1) Peneliti berkolaborasi dengan kepala sekolah dan wakasek Kurikulum. 2) Membuat rencana untuk supervisi kelas untuk perbaikan. 3) Menyiapkan jadwal supervisi. 4) Meyiapkan instrumen penelitian diantaranya angket komitmen tugas dan lembar pengamatan kompetensi pedagogik guru. 5) Menyiapkan daftar hadir

\section{Pelaksanaan}

Siklus kedua hampir sama dengan siklus pertama dan berdasarkan refleksi siklus pertama. Pelaksanaan siklus II dilakukan dari tanggal 17-29 September 2018 diadakan sosialisasi kegiatan PTS untuk meningkatkan komitmen tugas terhadap kompetensi pedagogik dengan adanya kegiatan supervisi yang akan dilakukan oleh kepala sekolah dibantu oleh wakasek kurikulum sebagai kolaborator. Kepala sekolah mengadakan pengarahan kembali tentang langkah-langkah perbaikan proses pembelajaran guna meningkatkan kompetensi pedagogik serta peningkatan komitmen tugas sebagai guru. Dari tanggal 17-28 September 2018 diadakan supervisi kelas kembali pada siklus kedua oleh kepala sekolah dan wakasek kurikulum. Pada akhir siklus kedua, guru mengisi angket komitmen tugas yang dibagikan oleh kepala sekolah secara jujur. Pada tanggal 29 September 2018 diadakan pertemuan untuk menarik kesimpulan dari hasil yang dicapai oleh peneliti saat pengamatan proses pembelajaran dan angket.

\section{Hasil observasi}

Pada siklus kedua, 16 orang atau $70 \%$ guru dengan kriteria amat baik, 7 orang atau $30 \%$ dengan kategori baik dan mencapai nilai rata-rata $73,2 \%$. Dengan demikian kompetensi pedagogik guru sudah meningkat dan sesuai dengan yang diharapkan dalam penelitian tindakan sekolah ini. Hasil angket komitmen tugas pada siklus kedua diantaranya bahwa kategori sangat tinggi ada 3 orang, kategori tinggi 14 orang, kategori sedang 5 orang dan kategori rendah hanya ada 1 orang dengan rata-rata nilai 81,93 termasuk pada kategori tinggi. 


\section{Refleksi}

Berdasarkan hasil observasi pelaksanaan pada siklus kedua, diantaranya kompetensi pedagogic guru yang sudah mencapai nilai rata-rata $73,2 \%$. Dengan demikian kompetensi pedagogik guru sudah meningkat dan sesuai dengan yang diharapkan dalam penelitian tindakan sekolah ini dengan indikator keberhasilan yaitu minimal $65 \%$ guru rata-rata mencapai kriteria amat baik. Sedangkan dari hasil angket komitmen tugas yang diberikan kepada guru, menyatakan rata-rata nilai 81,93 termasuk pada kategori tinggi. Dengan demikian berdasarkan hasil penelitian tindakan sekolah sudah mencapai indikator keberhasilan, maka penelitian dihentikan sampai pada siklus kedua saja.

Hasil observasi terhadap tindakan perbaikan siklus pertama dengan menggunakan intrumen penilaian kompetensi pedagogik guru yang hanya mencapai nilai rata-rata $65,4 \%$. Sedangkan dari hasil angket komitmen tugas yang diberikan kepada guru, menyatakan bahwa kategori rata-rata nilai 74,41 termasuk pada kategori sedang.

Sedangkan pada siklus kedua, berdasarkan hasil observasi, diantaranya kompetensi pedagogik guru yang sudah mencapai nilai rata-rata $73,2 \%$. berdasarkan dari hasil angket komitmen tugas yang diberikan kepada guru, menyatakan bahwa kategori rata-rata nilai 81,93 termasuk pada kategori tinggi.

SMA Negeri 1 Bola selalu mengedepankan kedisiplinan baik itu untuk siswa maupun gurunya. Kedisiplinan itu dimulai oleh kepala sekolah. Dari hasil pengamatan Kepala Sekolah biasanya berangkat lebih awal dan pulang lebih akhir. Karena sikap Kepala Sekolah SMA Negeri 1 Bola, guru-guru menjadi rajin dan segan jika datangnya terlambat. Kalau ada guru yang tidak masuk mengajar guru tersebut wajib memberi surat izin beserta alasan yang tepat tidak masuk mengajar dan wajib memberi tugas kepada peserta didik. Jadi meskipun guru tidak hadir siswa tetap bisa melakukan proses pembelajaran sebagaimana mestinya. Kedisiplinan tidak hanya ditujukan pada peserta didik akan tetapi guru juga perlu ditingkatkan kedisiplinannya karena guru sebagai contoh bagi peserta didiknya.

Kepala Sekolah SMA Negeri 1 Bola selalu memberikan motivasi agar komitmen tugas guru ditingkatkan, agar kompetensi pedagogik gurupun akan meningkat. Meningkatkan kompetensi profesional guru membutuhkan motivasi dan dukungan dari berbagai pihak, seperti halnya motivasi dari kepala sekolah, untuk lebih kreatif dan inovatif dalam proses pembelajaran di kelas serta disiplin dan komitmen tugas semakin baik dari semua guru guna menghasilkan siswa dengan lulusan terbaik.

Supervisi dilakukan dengan tujuan memberikan layanan dan bantuan untuk meningkatkan kualitas mengajar guru di kelas yang pada gilirannya untuk meningkatkan kualitas belajar siswa, bukan saja memperbaiki kemampuan mengajar tapi juga untuk pengembangan potensi kualitas guru. Sehubungan dengan hal itu, maka kepala sekolah sebagai supervisor hendaknya pandai meneliti, mencari dan menentukan syarat-syarat mana yang diperlukan bagi kemajuan sekolahnya sehingga tujuan pendidikan di sekolah itu tercapai dengan 
maksimal. Biasanya supervisi yang dilakukan di SMA Negeri 1 Bola dilaksanakan 1 kali dalam setahun. Dengan demikian melalui peran kepala sekolah dapat meningkatkan komitmen tugas terhadap kompetensi pedagogik guru. Hal ini berdasarkan pada hasil penilaian kompetensi pedagogik guru dan hasil angket komitmen tugas yang diberikan pada guru.

\section{KESIMPULAN}

Berdasarkan hasil penelitian diperoleh kesimpulan bahwa terjadi peningkatan komitmen tugas dengan nilai rata-rata 74,41 termasuk pada kategori sedang pada siklus pertama dan pada siklus kedua mencapai nilai rata-rata 81,93 termasuk pada kategori tinggi. Kompetensi pedagogik guru dengan nilai rata-rata $65,4 \%$ pada siklus pertama dan rata-rata $73,2 \%$ dengan ini bahwa penelitian dikatakan berhasil. Sesuai dengan hasil penelitian Fiqri (2020) Strategi kepala sekolah dalam meningkatkan mutu sarana dan prasarana pendidikan di SDIT Qurrota A'yun Ponorogo yaitu, kepala sekolah menggiatkan pengembangan sarana dan prasarana sekolah dengan mengajak kerjasama dengan beberapa pihak eksternal dan beberapa instansional dalam bentuk program-program yang telah dibentuk oleh sekolah. Selain itu kepala sekolah dalam meningkatkan mutu sekolah sering melakukan konsultasi dengan pihak tertentu untuk mengembangkan sarana dan prasarana sekolah.

\section{DAFTAR PUSTAKA}

Bernardin, H. John and Russel, E.A., 1993. Human resource Management, An Experiential Approach. Mc. Graw Hill International Edition, Singapore: Mac Graw Hill Book Co.

Departemen Pendidikan Nasional. 2005. Peraturan Pemerintah Nomor 19 Tahun 2005 tentang Standar Nasional Pendidikan. Jakarta: Depdiknas.

Departemen Pendidikan Nasional. 2005. Undang-Undang Nomor 14 Tahun 2005, Tentang Guru dan Dosen. Jakarta: Depdiknas.

Depdikbud. 2001. Panduan Manajemen Sekolah. Jakarta Direktorat Dikmenum.

Euis dan Donni. 2014. Manajemen Kelas (Classroom Management) Guru Profesional yang Inspiratif, Kreatif, Menyenangkan, dan Berprestasi. Bandung: Alfabeta.

Fred C. Lunenburg. 2013. Convergent Roles of the School Principal: Leadership, Managerial, and Curriculum-Instructional. International Journal of Education. Volume 1. Number 1. Diakses pada tanggal 07 April 2017.

Marselus R. Payong. 2011. Sertifikasi Profesi Guru; Konsep Dasar, Problematika, dan Implementasinya. Jakarta: PT Indeks Permata Puri Media.

Owens, Robert G. 2010. Organizational Behavior in Education. Allyn and Bacon. Boston.

Robbins, Stephen. 2000. Perilaku Organisasi. Klaten: PT. Intan Sejati. 
Solomon. 2007. Dimension of Teacher Behavior. Journal of Experimental. Education. Diakses pada tanggal 06 Februari 2017.

Sopiah. 2011. Perilaku Organisasi. Yogyakarta: Andi.

Suharsimi Arikunto. 2004. Dasar-Dasar Evaluasi Pendidikan. Jakarta: Bumi Aksara.

Sutomo. 2011. Manajemen Sekolah. Semarang: Universitas Negeri Semarang Press.

Syaiful Sagala. 2011. Supervisi Pembelajaran. Bandung: Alfabeta. Wahyudi. 2002. Manajemen Sumber Daya Manusia. Bandung: Sulita.

Winardi. 2012. Manajemen Perilaku Organisasi. Cetakan kedua. Jakarta: Kencana Prenada Media Group.

Wursanto. 2010. Dasar-Dasar Ilmu Organisasi. Yogyakarta: Andi. 